УДК 349.3

Ivan Yatskevych

\title{
RIGHT TO SOCIAL SECURITY OF EMPLOYMENT MIGRANTS IN EUROPEAN UNION
}

The article deals with the issue of social security of employment of migrants from third-countries to the European Union. This publication gives a short overview of literature and more detailed outlook of international, interstate, and national legal sources, conferring rights of third-countries workers employed in the EU. The author commences the analysis from the legal background for social security right safeguards. Following this goal, the documents of the Council of Europe are researched, particularly European Social Charter (revised). As per the EU regulation of migrants' right to social security guarantees, there are sources studied or referred to in the article. The Treaty of Lisbon and the EU directives are mentioned as legal sources, including latest development in the EU social security law.

It is stated on different approaches to social security provisions exercised by a Member State. The vision of problem of insufficient attention to victims of illegal employment of immigrants and their vulnerability is developed. Certain analysis of Association Agreement between Ukraine and the EU regarding social security, migration issues, and principles of cooperation in given sphere is presented.

Keywords: social security; right to work; trans-border employment, labour migration; human rights.

\section{Introduction}

There is rather vast literature on EU social policy, welfare and social rights guarantees in European states. Social standards and respect to human rights are widely discussed by researchers over the world. Perhaps the article by Herwig Verschueren is one of the most substantial recent papers within the topic of social security rights of third-country nationals under EU law [1].There are many other researchers concentrating their attention on legal aspects of social security, its legal issues. Those authors are, for instance, Eberhard Eichenhofer [2], Matti Mikkola [3], Peter Dwyer and Dimitris Papadimitriou [4], Tineke Dijkhoff [5], Viktor Kostiuk [6], Gaabriel Tavits [7] and many other researchers.

The right to social security is guaranteed and recognized on international level as social human rights. The development of human rights in Europe deals with a system of rights consisting of individual human rights, social human rights and group human rights. Thus, social human rights, and particularly right to social security, belong to the second generation of human rights.

This article covers research on legal issues of social protection of Ukraine as third-country employees according to various legal instruments of the Council of Europe, the European Union, bilateral and multilateral agreements, as well as some national Member State legislation.

Social rights protection within Council of Europe is regulated by several international agreements, such as European Social Charter (Revised), European Code of Social Security, European Convention on Human Rights. There is also the Charter of Fundamental Rights of the European Union regulating social security as a source of EU social security law.

The European Social Charter was opened for signature in 1961 and was politically predicted as kind of counteraction to Eastern bloc of countries declaring and providing worker's rights protection. So, the European Social Charter of 1961 among other social and economic rights guaranteed such welfare rights as social security, access to medical and social assistance, access to welfare services, protection of social rights [8]. It covers especially rights of those disadvantaged and threatened by social exclusion persons as mothers and families, children, the old, persons with disabilities, migrant workers and their families.

The European Social Charter has been designed as interstate treaty bearing obligations mostly for the State participating in the Charter but not necessarily delivering rights for individuals of those states. There was no procedure for individuals to make State to fulfil its obligations regarding social rights guaranteeing. But in 1995 a protocol allowing collective complaints by international and national organizations of employers and trade unions to the Committee of Independent Experts was added to the Charter. The usefulness of this instrument is highly discussed in the literature, and there are 15 member states of Council of Europe parties of mentioned

(C) Yatskevych I., 2018 
above Protocol to the Charter, given by 11/05/2018 [9]. Besides collective complaints option, the monitoring of Charter is being done via reporting system. But "the reporting system and the collective complaints serve different purposes and introduction of the latter will enhance the supervisory system of the Charter as a whole" [10, p. 123]. In 1996 revised European Social Charter, which updated and improved some of the provisions of the Charter 1961, appeared.

According to Article 12 of revised Social Charter, the Parties of the Charter agreed to take steps, by the conclusion of appropriate bilateral and multilateral agreements or by other means, and subject to the conditions laid down in such agreements, in order to ensure: (a) equal treatment with their own nationals of the nationals of other Parties in respect of social security rights, including the retention of benefits arising out of social security legislation, whatever movements the persons protected may undertake between the territories of the Parties; (b) the granting, maintenance and resumption of social security rights by such means as the accumulation of insurance or employment periods completed under the legislation of each of the Parties [11]. Besides that, the Article 14 of revised Social Charter provides right to benefit from social welfare services.

As it is stated in Handbook on European nonDiscrimination law, there is no right to social security under European Convention on Human Rights, but according to decisions by European Court of Human Rights some forms of social security are protected by Article 1 of Protocol No. 1 or Article 8, particularly property rights to pensions and other benefit payments [12, pp. 214-215].

In this article we shall pay attention mostly to EU regulation of migrant workers' social security and its relevance to Ukrainian nationals arriving to EU for employment reasons.

Legal approach to social security study is always a difficult topic. As it is stated in preface to Research Handbook on European Social Security Law by Frans Pennings and Gijsbert Vonk, the body of social security laws consists of diverse set of rules, differing on range of subjects, as well as they are diverse "fundamentally in nature". On the one hand, there are grand principles with legal status, such as right to social security as a human right. On another hand, there are many technical provisions regarding "exchange of forms between social security institutions, the mutual recognition of certain statutory definitions of invalidity and the sharing of costs of benefits paid to migrant workers". Besides that there are many norms and principles that have nothing to do with social security as such but which directly or indirectly influence the operation of social security law such as competition law, property law, directives on insurance law, transfer undertakings $[13$, p. xi] etc., and we would add employing migrant workers from outside the EU to this list as well.

The point is the social security relationships in Europe are subject to regulation and research as an element of national social security system, as well as a subject of regulation by EU law and sources of law adopted by such European organization as Council of Europe. In addition, there are some multilateral or bilateral treaties regulating, particularly, relationships of social security rights and migrant work. So, there is wide range of legal sources of social security law, including right to social security of migrant workers coming from third countries, which are not member states of EU. In case of Ukraine, there is relatively new and complex legal source to be applied in different spheres of relations between EU and Ukraine - the Association Agreement between the European Union and its Member States, of the one part, and Ukraine, of the other part [14].

\section{Social Security Rights in the Primary and Secondary EU Legislation}

The concept of flexible social security policy in EU is covered with term flexicurity which presupposes balancing public and business interest in matters of social wellbeing. This concept is highly discussed in the literature as well [15-18]. Even though the tradition of social solidarity in Europe is deeply rooted and has over century long history, there are different approaches and developments regarding social rights safeguarding and protection in European states.

According to Lisbon Treaty, which came into force in 2009, Member States have competence in the field of labour migration and Member States have right to determine the volumes of admission of third-country nationals to their territory to seek work. It allows each Member State to build quite flexible migration policy, including employment migration. But the same time the Treaty of Lisbon declares that the EU immigration policy shall ensure fair and non-discriminatory treatment of thirdcountry nationals residing legally in Member States.

In the European Union law there are many norms against discrimination. But only the Racial Equality Directive contains wide protection against discrimination in accessing the welfare system and social protection. Nevertheless, there are several EU Directives on labour migration 
covering issues of employment and social security. These Directives deal with the following groups of migrants from third countries: students (Directive 2004/114/EC) and researchers (Directives 2005/71/EC, (EU) 2016/801); highly qualified workers ("blue card" holders, Directive 2009/50/EC); illegally staying third-country migrants (Directive 2009/52/EC); seasonal workers (Directive 2014/36/EU); intra-corporate transferees (Directive 2014/66/EU) and some other categories, covered by 'Single Permit' Directive (Directive 2011/98/EU), for example. Let us look closer EU regulation for researchers' employment and social security rights safeguards.

New EU legislation on social security and employment rights of students and researchers is updated and covered in Directive (EU) 2016/801. It delivers improved legal regulation applicable both to researches and students. The main idea of this Directive is the guarantee for equal treatment with regards to inter alia working conditions and membership to workers organizations and branches of social security, exporting old-age pensions to a third country to the extent it is provided for nationals of Member State involved (Directive 2011/98/EU). But the Article 22 of the Directive (EU) 2016/801 allows Member States to withdraw or refuse to renew an authorisation where the terms of employment according to national law or collective agreements or practices are not met by host entity employing third-country nationals; or such employer is sanctioned in accordance with national law for undeclared work; or such employer failed to meet its legal obligations on taxation, social security, labour rights or working conditions.

\section{International Treaties and interstate Agreements on Social Security for Employment Migrants}

The system of international wide regulation of social security rights protection is quite developed and is still developing according to current social, political and economic challenges in the world and Europe especially. In the meantime, right to social security competes with freedom to conduct a business, one of the rights in the Charter of Fundamental Rights of the European Union due to market orientation and weakening or softening social security standards in EU under agenda of flexicurity. But correlation between freedom to conduct a business and the rights of employees depends on legislation of an EU Member State. Some States, for instance, admit concluding socalled "zero-hours contracts", hiring a person as an independent contractor, but other States consider this kind employment illegal, because of its adverse impact on social security and disbalancing employment relationships as such. It is important to draw attention to problem of possible exploitation of migrant workers from third countries, especially regarding illegal employment immigrants, doing precarious work in precarious conditions [19]. There is a high-level risk of breaking rights for social security of those migrants, and this risk is to be dealt on both on the EU level and on Member State level.

There are different monitoring institutions with workplace inspection roles in different EU member states and they focus on: ensuring compliance with rules on social security, as well as on working conditions, working hours, the minimum wage, and health and safety. As it is state in the literature, "some of these authorities - for example in Finland, Poland and Slovakia - are also obliged to monitor the foreign workforce and ensure compliance with the country's immigration law" [19, p. 63]. But migrant workers from third countries belong to the most vulnerable categories, even the persons employed legally in a member state. Employment and social security policy in EU member states mostly focused on monitoring and inspecting offender or employer rather than employment migrants social and economic rights protection. Thus, lack of victim-focus approach towards for example migrant employees leaves them in even more miserable situation than they have been before intervention of authorities inspecting their employer. Those migrants are pushed over the margin of homeless and unemployed persons, suffering together with their families.

There is a problem of guaranteeing illegal migrants' social security right, as well as other social and economic rights derived from employment relationship. Some countries of the European Union, like the Netherlands, provide victims of employment exploitation with information on their right to claim for compensation. Other countries, like Austria, depending on province policy, "supports victims of labour exploitation in filing their civil law claims, particularly for back payment of denied wages and payment for denied social security contributions," but some of them have denied legal representation in cases of outlaw employment [19, p. 82].

\section{EU - Ukraine Association Agreement on Migrant Employees Social Security}

The Association Agreement between Ukraine and EU has been ratified and come to forth in 2014 . 
Since this Agreement, according to its Preamble, appeared due to commitment of the Parties to "increasing dialogue based on the fundamental principles of solidarity, mutual trust, joint responsibility and partnership - and cooperation on migration, asylum and border management, with a comprehensive approach paying attention to legal migration and to cooperating in tackling illegal immigration, and trafficking in human beings, and ensuring the efficient implementation of the readmission agreement" [14], it is worth to examine provisions of the Association Agreement regarding social security of migrants working in a Party's side. The issues of migration flow are regulated by Article 16 which covers cooperation on migration, asylum and border management. The dialogue between Parties, following recently cited Article 16 $\S 1$, is based on the fundamental principles of solidarity, mutual trust, joint responsibility and partnership. Among other things, cooperation on migration, asylum and border management will focus on exchanging views on the informal employment of migrants.

The next Article 17 of the Association Agreement is titled Treatment of workers and the $\S 1$ Article 17 reads: "Subject to the laws, conditions and procedures applicable in the Member States and the EU, treatment accorded to workers who are Ukrainian nationals and who are legally employed in the territory of a Member State shall be free of any discrimination based on nationality as regards working conditions, remuneration or dismissal, compared to the nationals of that Member State." Thus, Ukrainians employed in a Member State of EU must be treated without any discrimination at work.

In the meantime, issues of mobility of workers (Article 18 of Association Agreement) is to be regulated according to labour market situation in a Member State and is subject to legislation and rules in force in such State. According to Association Agreement the existing system of bilateral agreements between Ukraine and a Member State shall preserve and if possible improve. Besides that, it is expected other Member State to examine the possibility of concluding similar agreements. The association Agreement leaves room for providing more favourable provisions in additional areas depending on situation on labour market.

In case of temporary presence of natural persons for business reasons in the territory of EU members, those persons' employment presupposes application to them all the requirements of the state of employment laws and regulations regarding entry, stay, work and social security measures.

\section{Conclusion}

As we can see from given above text the European Union law as well as legal instruments adopted under Council of Europe stress upon nondiscrimination and equality in employment and social security rights of third-country nationals comparing to host state nationals. While international documents focus on equality, the European Union directives provide Member States with opportunity to set up different rules of migrants' work coming from outside the EU. Naturally, the economic and social situation in each country of the EU is different. So, they tend to gain from common values and principles of the Union and the same time Member States always try to protect their markets from extra burden of social security obligations caused at employment of third-country national. This situation creates grounds for positioning migrant workers in less favourable situation than citizens of the EU Member State.

If legal employment migrants have rights for equal working conditions and social security not less than nationals of a Member State, the illegal employees are in much more difficult situation. Each Member State controls employment and social security rights observance at employing migrants, but the measures to be taken in case of breach of law are focused mostly on employers and not on suffered party which is employee. It means that as a result illegal migrant worker or an immigrant employed in contrary to norms and rules, loose their jobs and resources to support their families.

Unfortunately, it is not possible to show judgements of European Court on Human Rights, as well as European Court of Justice regarding nondiscrimination at employment and social security due to limitation in size of this article and high importance of judicial practice on this issue. But this part of the subject covered in this publication may be subject for a separate research paper.

In the meantime, Association Agreement between Ukraine and the European Union confers right to employment and social security free of discrimination for Ukrainian nationals, but only for those who are employed legally. The Association Agreement reaffirms validity of interstate agreement including employment and social security issues. Even more, it encourages other Member States to conclude such agreements in accordance with mutual benefit and national interests. Anyway, illegal migration is not acceptable conform the EU law, national legislation and interstate agreements, even though it may be profitable and desirable for parties of employment contract. In my opinion, 
social rights as human rights, including right to social security, is guaranteed and must be preserved and supported by Member States and Ukraine. Probably, intensification of cooperation between Ukraine and the EU, as well as new economic achievements of Ukraine, including foreign investments and new jobs appearing may give better alternative for Ukrainian (il)legal migrants for employment and social security right exercising in their home state.

\section{References}

1. H. Verschueren, "Employment and Social Security Rights of Third-Country Labour Migrants under EU Law: An Incomplete Patchwork of Legal Protection," Eur. J. Migr. Law, vol. 18, no. 4, pp. 373-408, Nov. 2016.

2. E. Eichenhofer, "How to Simplify the Co-Ordination of Social Security," Eur. J. Soc. Secur., vol. 2, pp. 231-240, 2000.

3. M. Mikkola, Social human rights of Europe. Porvoo: Karelactio, 2010.

4. P. Dwyer and D. Papadimitriou, "The social security rights of older international migrants in the European Union," J. Ethn. Migr. Stud., vol. 32, no. 8, pp. 1301-1319, 2006.

5. T. Dijkhoff, International social security standards in the European Union: the cases of the Czech Republic and Estonia. Cambridge etc.: Intersentia, 2011.

6. V. L. Kostiuk, "Social rights in welfare state: the concept, issues and prospectives at conditions of post-soviet society transformation," in Development and modernization of the legal systems of Eastern Europe: experience of Poland and prospects of Ukraine, Collective monograph, vol. 1, Lublin: Izdevnieciba "Baltija Publishing," 2017, pp. 163-182.

7. G. Tavits, "International Standards for Social Security and Their Fulfilment in Estonia: Changes in Pension and Health Insurance and Their Constitutionality," Juridica Intl, vol. 18, p. $27,2011$.

8. "ETS No. 035 - European Social Charter Turin, 18.X.1961." Online. Available: https://www.coe.int/en/web/conventions/searchon-treaties/-/conventions/treaty/035 Accessed: 11-May-2018.

9. "Chart of signatures and ratifications of Treaty 158," Treaty Office. Online. Available: https://www.coe.int/en/web/ conventions/full-list Accessed: 11-May-2018.

10. The Social Charter of the 21st Century. Council of Europe, 1997.
11. "CETS 163 - European Social Charter (Revised)." Online. Available: https://rm.coe.int/CoERMPublicCommonSearchSer vices/ DisplayDCTMContent?documentId $=090000168007 \mathrm{cf93}$ Accessed: 13-Apr-2017.

12. Europäische Union, Europarat, and Europäischer Gerichtshof für Menschenrechte, Eds., Handbook on European nondiscrimination law, 2018 edition. Luxembourg: Publications Office of the European Union, 2018.

13. F. Pennings and G. Vonk, Research Handbook on European Social Security Law. Edward Elgar Publishing, 2015.

14. "Association Agreement between the European Union and its Member States, of the one part, and Ukraine, of the other part," Off. J. Eur. Union, vol. I, no. 161/3, May 2014.

15. B. Burchell, "Flexicurity as a moderator of the relationship between job insecurity and psychological well-being," Camb. J. Reg. Econ. Soc., vol. 2, no. 3, pp. 365-378, 2009.

16. P. Emmenegger, "The Long Road to Flexicurity: The Development of Job Security Regulations in Denmark and Sweden: The Long Road to Flexicurity," Scand. Polit. Stud., vol. 33, no. 3, pp. 271-294, 2010.

17. L. J. Nichols, "Labour Market Policies in Denmark and Canada: Could Flexicurity be an Answer for Canadian Workers?," Social. Stud., vol. 8, no. 2, pp. 163-188, 2012.

18. M. P. Klindt, "From Rhetorical Action to Policy Learning: Understanding the European Commission's Elaboration of the Flexicurity Concept," JCMS J. Common Mark. Stud., vol. 49, no. 5, pp. 971-994, 2011.

19. Severe labour exploitation: workers moving within or into the European Union. States' obligations and victims' rights. Viena, 2015.

\section{Яичкевич I. I.}

\section{ПРАВО НА СОЦІАЛЬНЕ ЗАБЕЗПЕЧЕННЯ ТРУДОВИХ МІГРАНТІВ У СВРОПЕЙСЬКОМУ СОЮЗІ}

Статтю присвячено питанням соціального захисту трудових мігрантів з третіх держав до Європейського Союзу. Подано стислий огляд літератури та більш докладний огляд системи джерел правового регулювання відносин соціального захисту працівників з держав, що не входять до ЄС. Законодавство ЄС розглянуто в контексті міжнародного та у зв'язку з актами Ради Європи, зокрема Європейської соціальної хартії (переглянутої).

Основним принципом правового регулювання соціального захисту працівників-мігрантів, згідно з європейським первинним та вторинним законодавством, $є$ гарантування рівноцінних умов праці та соціальних прав порівняно з громадянами держави працевлаштування, водночас допускається встановлення кожною державою ЄС власних правил та норм щодо залучення праці мігрантів відповідно до соціального, політичного та економічного становища окремої держави ЄС. Відтак важливу роль відіграють міжнародні двосторонні договори про взаємне визнання та забезпечення соціальних прав громадян Сторін таких договорів. Щодо трудових мігрантів з України важливе значення має Угода про асоціацію України з СС та державами-членами ЄС.

Яскравою демонстрацією недостатньо дієвого нормативного забезпечення соціальних прав працівників 3 третіх держав є Директива ЄС 2016/801, яка закріплює принцип рівного ставлення до науковців-нерезидентів, що працевлаштовуються в одній із держав ЄС. Тобто це відповідає міжнародним та європейським принципам недискримінації та рівного ставлення в трудових відносинах, водночас стаття 22 вказаної директиви дозволяє державам відкликати або не поновлювати 
дозвіл на працевлаштування, якщо під час працевлаштування або в процесі виконання умов трудового договору роботодавцем було порушено законодавство, недотримано соціальних гарантій тощо і притягнуто до відповідальності такого роботодавця. Тож такі працівники втрачають можливість працювати та гарантії права на соціальний захист, що ставить їх та їхні родини в критичне економічне та соціальне становище. Зрештою, працівники-мігранти потрапляють до найбільш вразливої категорії працівників, причому як легально працевлаштовані, так і нелегально. Вважаємо, що така незахищеність працівників-мігрантів призводить до експлуатації цих осіб роботодавцями, порушення прав людини, порушення конкурентного середовища на ринку праці або принаймні створює для цього передумови.

Важливою складовою гарантування соціальних прав працівників-мігрантів у державах ЄС $\epsilon$ практика ЄСПЛ та Європейського суду справедливості. Оскільки рішення та практика ЄСПЛ визнаються джерелом права в Україні, а рішення Суду справедливості можуть враховуватися при тлумаченні національного законодавства відповідно до усталених стандартів ЄС, то подальші дослідження в цьому напрямку матимуть важливе теоретичне та практичне значення, зокрема й для України.

Ключові слова: соціальне забезпечення, право на працю, транскордонне працевлаштування, трудова міграція, права людини. 